\title{
Africanacity of International Investment Law: A Reflection on Investment Agreements in Africa
}

\author{
Ally Possi*
}

\begin{abstract}
In recent times, we have been witnessing the re-making of international investment law (IIL) architect maiden from Africa. The reforms shift the IIL paradigm by establishing adequate policy space to the host state, reiterating state sovereignty and, significantly, introducing obligations imposed on the foreign investors. Alongside these reforms, Africans are persistently negating the speculative imbalanced international investorstate dispute settlement (ISDS) system by suggesting local alternatives. These reforms can be traced to the Pan African Investment Code of 2016, which shapes the African IIL agenda. Thus, this monograph discusses Africa's recent surge of reforms on IIL which transform the traditional regime. These commendable reforms give African states an opportunity to "regulate" IIL and guard their own interests. Yet the reforms are already showing some signs of incoherence, particularly on the binding nature of investment treaty models and on ISDS mechanisms, which may potentially negate the thrust of what this monograph dubs as the "Africanacity" of IIL.
\end{abstract} Keywords: Africanacity, International Investment law, Investment Treaty Model, ISDS, RECs, Sub-regional. DOI: $10.7176 / \mathrm{JLPG} / 113-01$

Publication date:September $30^{\text {th }} 2021$

\section{Introduction}

In recent decades, African states have been transforming international investment law (IIL) through treaty reforms and the enactment of domestic law. ${ }^{1}$ These reforms provide a genuine gesture of what this monograph dubs as the Africanacity of IIL. The reforms redirect the historical path that most African countries have had to follow as constrained by the unexpected outcomes of receiving foreign investment. The current developments in investment law and policy in Africa are driven by Africa and permeate through bilateral, regional and global international instruments. Ordinarily, the IIL regime is subject to customary international law, bilateral, regional, and multilateral investment treaties, and free trade agreements (FTAs) with specific investment provisions or chapters. $^{2}$ In this monograph, the stated reforms are dubbed as the "Africanacity" of IIL. The term is used in the sense of preserving African interests in establishing investment policy, legal and institutional frameworks that govern IIL.

There is a surge of IIL transformation through regionalism in the entire world, ${ }^{3}$ and African intergovernmental organisations are not to be left behind as this takes place. It comes at a time when most of the investment agreements in Africa were endorsed during the post-colonial era, the time in which African states were desperate to reinvent their economies. ${ }^{4}$ During that period the field was notorious ${ }^{5}$ (in fact, it still is) for the complicity of investors in the host states and the controversies they generated, ${ }^{6}$ including the jurisprudence emanating from the arbitral tribunals.

IIL in Africa is dominated by bilateral investment treaties entered into between African countries and

\footnotetext{
${ }^{*}$ LLB (Mzumbe); LLM (UCT); LLD (Pretoria) Post-Doctoral Fellow (North-West University, South Africa); Advocate of the High Court of Tanzania/Zanzibar; Deputy Permanent Secretary, Ministry of Information, Culture, Arts and Sports - United Republic of Tanzania (ally.possi@hotmail.com). Views expressed in this article do not in any way express views of the Government of the United Republic of Tanzania.

${ }^{1}$ See Akinkugbe, O.D., “Africanization and the reform of international investment law", Case Western Reserve Journal of International Law, 53.1, 2021, pp. 7-32. For novelty on Africanisation of International investment law see: Nagar D. \& Mutasa C., Africa and the world: bilateral and multilateral international diplomacy, Cham: Springer, 2018; Mbengue M. M \& Ngangjoh-Hodu Y. (eds), African perspectives in international investment law. Manchester, Manchester University Press, 2020; Schill S.W., "The New African Regionalism in International Investment Law", Journal of World Investment \& Trade, 18.3, 2017, pp. 367-369; Gathii J.T., "Agreement Establishing The African Continental Free Trade Area", International legal materials, 58.5, 2019, p. 1028-1083; Adeleke F., International investment law and policy in Africa: exploring a human rights based approach to investment regulation and dispute settlement, Oxon: Routledge, 2017; Odularu G. \& Bamidele A., Negotiating south-south regional trade agreements : economic opportunities and policy directions for Africa, Cham, Springer Nature, 2017; Nwankwo C.M., "Balancing international investment law and climate change in Africa: assessing vertical and horizontal norms", Manchester Journal of International Economic Law, 17.1, 2020, p. 48-63; Collins D., An Introduction to international investment law, Cambridge: Cambridge University Press, 2017 at 39.

${ }^{2}$ Investment policies and bilateral investment treaties in Africa: implications for regional integration, United Nations Economic Commission for Africa (Feb. 2016), https://www.uneca.org/sites/default/files/PublicationFiles/eng (accessed 24 July 2021).

3 Akinkugbe O.D., "Theorizing developmental regionalism in narratives of African regional trade agreements", African Journal of International Economic Law, 1.1, 2020, pp. 291-320.

${ }^{4}$ Mbengue M.M. \& Schacherer S., "The 'Africanization' of international investment law: the pan-African investment code and the reform of the international investment regime", Journal of World Investment \& Trade, 18.3, p. 437-448, at 437.

${ }^{5}$ See Sornarajah M., The international law and foreign investment, Cambridge: Cambridge University Press, 2004.

${ }^{6}$ See generally, Odumosu I.T., "The antinomies of the continued relevance of ICSID to the third world", San Diego International Law Journal , 8.1, 2007, pp. 345-384, at 346.
} 
advanced economies in Europe and the United States. Many of these BITs are perceived to curtail the sovereignty of the host-state, to limit its regulatory powers and ultimately to undermine its capacity to develop efficient policies in different spheres such as natural resources, health, the environment and the like. Once it had been realized that the existing BITs were causing extraordinary damage, the surge of regional and national reforms of investment law was inevitable. That is why, today, there is a sharp rise in African regionalism on IIL. The Continent is establishing its own bragging rights to regulate IIL. The newly formulated IIL norms promote African interests first and foremost. Still, IIL is extraordinarily fragmented and reshaping IIL it an unfortunately complex process leading to a diverse set of instruments with competing norms. ${ }^{1}$ It is also a fact that Africans are not used to adopting their own model BITs when entering into agreements with the developed world.

The Pan African investment Code (PAIC) represents a Continental consensus in shaping IIL. ${ }^{2}$ The Code bequeathed the spirit of Africanacity to most of the newly adopted investment model treaties in Africa. For instance, most of the sub-regional investment model treaties categorically state their overarching objective to enhance investment in sustainable development. Other features include the introduction of investors' obligations, the promotion and protection of the environment, social development and human rights, transparency, corruption, public scrutiny, economic development, and corporate responsibility. These provisions are rare in the ordinary BITs. In inserting such clauses, policy space is ensured, and national sovereignty and public interest are not undermined at the expense of attracting and protecting foreign investors.

International Investment Agreements (IIA) are generally tools for attracting Foreign Direct Investments (FDIs), deepening regional integration, and increasing diplomatic relations with the developed world. ${ }^{3}$ In parallel with the ongoing transformations, developing economies like China, India, Brazil and Indonesia are increasingly becoming influential as top FDIs in Africa and, as a consequence, more and more IIAs are concluded between African countries and such economies - South-South. ${ }^{4}$ Lately IIAs have reflected the interests of sustainable development, environmental issues and human rights. Regardless of Africa's entertaining numerous IIAs to attract FDI, yet the result is perhaps not always what is expected..$^{5}$ Aspects which are often not expected by Africans is that FDI in Africa is marred by corruption, the incompletion of the investment projects, and illicit financial flows, which features are also to blame for curtailing the benefits of FDI in the Continent, apart from the traditional IIL regime.

We are still debating as to whether foreign investment attracts economic advancement to a host state. ${ }^{6}$ Some argue that foreign investment embeds the imperial and capitalist interests of multinational corporations to the detriment of host states. ${ }^{7}$ To most developing countries, it is now a longstanding view that IIL entrenches the interest of investors only. ${ }^{8}$ To this juncture, debates over the relevance of foreign investment still linger. ${ }^{9}$ Nevertheless, current IIL reforms target laws and policies which are development-oriented and that attempt to strike a balance between investor and host-state rights and investors" obligations. Thus, the "Africanacity" of IIL is transforming Africa from being "rule-takers" to "rule-makers". 10

Another key feature of the Africanacity of IIL is the localisation of the investor-state dispute settlement system (ISDS). Traditional BITs contain clauses for settling investment disputes, affording investors and even host-states an opportunity to have access to a natural forum in case of a future dispute against a host state. ${ }^{11}$ The

${ }^{1}$ Chidede T., "The right to regulate in Africa's international investment law regime", Oregon Review of International Law, 20.2, 2019, pp. 437-468, at 437 .

${ }^{2}$ Mbengue M.M. \& Schacherer S., "Africa and the rethinking of international investment law: about the elaboration of the Pan-African Investment Code", in Roberts A. et al (Eds), Comparative international law, Oxford: Oxford University Press, 2018, pp. 547-569, at 547.

${ }^{3}$ See generally: Vandevelde K. J., "The political economy of a bilateral investment treaty", American Journal of International Law 92. 4, 1998, pp. 621-641; Nam J., "Model bit: an ideal prototype or a tool for efficient breach?", Georgetown journal of international law, 48.4, 2017, pp. 1275-1308; Fox G., "A Future for International Investment: modifying Bits to drive economic development," Georgetown Journal of International Law, 46.1, 2014, pp. 229-260; Sauvant K. P., \& Lisa E. S., The effect of treaties on foreign direct investment: bilateral investment treaties, double taxation treaties, and investment flows, New York: Oxford University Press, 2009.

${ }^{4}$ Mbengue M.M. \& Schacherer S., "The 'Africanization' of international investment law: the pan-African investment code and the reform of the international investment regime", Journal of World Investment \& Trade, 18.3, p. 437-448, at 438.

${ }^{5}$ See Adams K., Debrah Y.A., Williams K., \& Mmieh F., "Causes of Financial FDI Inflows into Sub-Saharan Africa (SSA) Evidence from Ghana", Thunderbird International Business Review, 56.5, 2014, pp. 439-459; Cleeve E.A, Debrah Y., \& Yiheyis Z., "Human capital and FDI inflow: an Assessment of the African case", World Development, 74.c, 2015, pp. 1-14.

${ }^{6}$ Dagbanja D., "Can African countries attract investments without bilateral investment treaties? example from Ghana", The Australasian Review of African Studies, 40.2., 2019, pp. 71-89; Van Harten G., "Five justifications for investment treaties: a critical discussion", Trade, Law \& Development, 2.1, 2010, pp. 19-58.

${ }^{7}$ Ho J., "The creation of elusive investor responsibility," American Journal of International Law, 113, 2019, pp. 10-15.

${ }^{8}$ Van Harten G., Investment treaty arbitration and public law, Oxford: Oxford University Press, 2009, at 3-8.

${ }^{9}$ Asante S.K.B., "international law and foreign investment: a reappraisal”, The International and Comparative Law Quarterly, 37.3, 1988, pp. $588-628$, at 616

${ }^{10}$ Kamau N., "Investment law and treaty reform in Africa: fragments and fragmentation", African Journal of International Economic Law, $1.1,2020$, pp. 201-231, at 230 .

${ }^{11}$ See Sornarajah M., The International Law on Foreign Investment, Cambridge: Cambridge University Press, 2010, pp. 216; Osmanski E., "Investor-state dispute settlement: is there a better alternative", Brooklyn Journal of International Law, 43.2, 2018, pp. 639-664. 
International Centre for the Settlement of Investment Disputes (ICSID) is seen as a universal tribunal for adjudicating investment arbitration disputes. Some accuse it of being a tool used by "imperialists" to weaken emerging economies such as those of Africa. ${ }^{1}$

Traditional BITs have established a platform in which foreign investors can snub the domestic courts of the host states and submit their investment claims directly to international arbitral tribunals, mostly based overseas. In such an arrangement, African countries find themselves exposed to the risk of legal disputes and hefty fines which put a further strain on scant government resources and narrow the policy space when designing policies which touch on investment. That is why the emerging African approach on ISDS is to negate the international ISDS mechanism by preferring amicable settlement as the first option. If that is unsuccessful then arbitration can proceed, but it is to be conducted by national institutions using national laws, after "exhausting available remedies"

The primary purpose of this contribution is to present the existing IIL reforms in Africa. In the process, the contribution will establish the applicability and suitability of the reforms. In doing that, there are seven sections in this contribution. The first section is a general introductory one introducing the subject matter. The second section presents the African position under the traditional IIL regime. The third section presents the African reforms at the Continental level, focusing mainly on the adopted PAIC. In accordance with the regional approach, the regional economic communities (RECs) are in place to complement the institutional and normative architecture of the continental or regional system. Thus, the fourth section demonstrates the extent to which these RECs have started to transform IIL in the spirit of Africanacity. The article then proceeds to the fifth section, that presents the domestic approaches to IIL. A special section on the African approach to the ISDS mechanism is provided in this contribution, as this is seen as the most debatable aspect of the current IIL reforms. And finally, the seventh section provides some concluding remarks on the subject.

\section{Africa and IIL at the Global Level}

Most African countries have signed and ratified a number of instruments pertaining to IIL at the global level. Some of these agreements include the World Trade Organization (WTO) Agreement on Trade-Related Investment Measures (TRIMs) ${ }^{2}$, the WTO General Agreement on Trade in Services (GATS) ${ }^{3}$, the Convention Establishing the Multilateral Investment Guarantee Agency (MIGA Convention) ${ }^{4}$, the Convention on the Settlement of Investment Disputes Between States and Nationals of Other States (ICSID Convention) ${ }^{5}$, and the New York Convention on the Recognition and Enforcement of Foreign Arbitral Awards (New York Convention $)^{6}$. Under the principles of international law, as state parties they have pledged to take all legal, political and administrative measures to adhere to the requirements of the treaties as encapsulated in their provisions. Also, BITs concluded in the 1990s and early 2000s are landmark features of Africa's involvement in IIL. ${ }^{7}$

TRIMs ensures that some of the investment measures do not restrict trade from a national treatment. ${ }^{8}$ The agreement is applicable to investment measures related to trade in goods only. By regulating trade in services, GATS aims at creating a credible and reliable system of international trade rules; ensuring fair and equitable treatment of all participants (the principle of non-discrimination); stimulating economic activity through guaranteed policy bindings; and promoting trade. ${ }^{9}$ All WTO members are subscribers to GATS. The MIGA Convention aims at protecting foreign investors against political and non-commercial risks such as expropriation, the restriction of transfer, breach of contract, the failure to honour financial obligations, as well as war, terrorism, and civil disturbance. ${ }^{10}$ The Agency was established simply to protect first-world companies against the deprivations of developing nations. ${ }^{11}$

In 1965 the World Bank established the ICSID. To date, the ICSID is one of the major global entities of

\footnotetext{
${ }^{1}$ Schultz T., \& Dupont C., "Investment arbitration: promoting the rule of law or over-empowering investors? a quantitative empirical study", European Journal of International Law, 25. 4, 2014, pp. 1147-1168, at 1148.

${ }^{2}$ Agreement on Trade-Related Investment Measures, Annex IA, Apr. 15, 1994, 1868 U.N.T.S. 186.

${ }^{3}$ General Agreement on Trade in Services, Annex IB, Apr. 15, 1994, 1869 U.N.T.S. 183, 33 I.L.M. 1167.

${ }^{4}$ Convention Establishing the Multilateral Investment Guarantee Agency, Oct. 11, 1985, 1508 U.N.T.S. 99. The MIGA Convention was signed in 1985 and came into operation on 1988.

${ }^{5}$ Convention on the Settlement of Investment Disputes Between States and Nationals of Other States, Oct. 14, 1966, 575 U.N.T.S. 159.

${ }^{6}$ Convention on the Recognition and Enforcement of Foreign Arbitral Awards, May 20, 1958, 330 U.N.T.S. 38.

${ }^{7}$ Mbengue M.M., \& Schacherer S., "Africa and the rethinking of international investment law: about the elaboration of the Pan-African Investment Code", in Roberts A. et al (Eds), Comparative international law, Oxford: Oxford University Press, 2018, pp. 547-569, at 548.

${ }^{8}$ See art 1 of TRIMs.

${ }^{9}$ Indira C., Hossain J.B., \& Alam S., International Trade Law and the WTO, Annandale, N.S.W: Federation Press, 2013; Keet D., The World Trade Organisation: General Agreement on Trade in Services : from forcing "liberalisation" to reinforcing privatisation!: from the further "opening up" of all economies to the furthering re-colonisation, Cape Town: Alternative Information and Development Centre, 2003.

${ }^{10}$ Art 2 of the MIGA Convention.

${ }^{11}$ See Peter C.M., "MIGA and GRIP: two international investment insurance programmes", World Competition, 12.3, 1989, pp. 95-104; Rowat M.D., "Multilateral approaches to improving the investment climate of developing countries: the cases of ICSID and MIGA", Harvard International Law Journal, 33., 1992, pp. 103-144.
} 
arbitration for the resolution of disputes between foreign investors and host-states. It represents perhaps the single greatest success in the multilateralism of international investment law. ${ }^{1}$ The New York Convention regulates the recognition and enforcement of foreign arbitral awards. ${ }^{2}$ The Convention simply requires member states to recognise and enforce a judgment or an arbitral award from the territory of another state other than where recognition and arbitration is sought. ${ }^{3}$ Africa views ICSID ${ }^{4}$ and the New York Conventions as notorious instruments in arbitration dispute. While African countries have consciously committed to these instruments, it is now apparent that most African legal scholars and practitioners believe that these instruments have created entities and legal mechanisms to ensure that the developed world succeeds whenever facing arbitral or legal challenges with regard to Foreign Direct Investment. Such assertions should not be down-played lightly, even though there African countries are sometimes at fault. The most notable faults are corruption and the unpredictability of laws and policies.

Despite the African protests against the current IIL, reforms in the regime have commenced. African states are participating in the reform processes, as is the rest of the world. ${ }^{5}$ The process is founded on two pillars: procedural reform through the United Nations system at UNCITRAL, and the revision of the ICSID Rules.

Ironically, however, the same countries who are now protesting against the traditional IIL regime are those who are signatories to the protested IIAs. Perhaps questions should be asked about the level of awareness, the commitment and the intentions of those participating in enforcing their international obligations. Nevertheless, what is clear is that the current IIL regime is not balanced, especially on the level of expertise between those coming from the developed nations who appear to have vast knowledge of and experience in the area, and those from the developing economies, who for a long time have been engaged in IIL as a means of attracting investment into their territories and as a means of improving diplomatic relations. It is believed that Africa will take seriously these reforms under the UNCITRAL and ICSID Rules. In any case, Africans should broaden their expertise in the area in order to benefit from the IIL regime, instead of boycotting it.

\section{IIL for Africa, of Africa, by Africans}

The African Union (AU) is endeavouring to establish the African Economic Community and the Continental Free Trade Area (AfCFTA) by 2034. ${ }^{6}$ On May 30, 2019 the AfCFTA agreement came into force. There are other frameworks that led to the ratification of the AfCFTA, such as the 1980 Lagos Plan of Action for the Development of Africa, and the Abuja Treaty, which proposed the establishment Regional Economic Communities, which are regional groupings of African states, as the basis of wider African integration for regional and ultimately continental integration. The attraction of investment is key to utilising the benefits of AfCFTA.

Africa is yet to have a binding investment instrument. The Continent's regulatory framework is disjointed, consisting of BITs, regional investment agreements and free trade agreements with investment provisions. There was a consensus that a need for a comprehensive guiding instrument on investment was imminent, for improving trade and investments necessary to the growth and development of Africa. In 2017 the AU adopted a nonbinding continentwide investment policy, the Pan-African Investment Code (PAIC). ${ }^{7}$ Initially the Code was intended to be a binding Treaty, only for African states not to find sufficient common interest to promulgate a binding instrument. ${ }^{8}$ The Code is nevertheless the anchor upon which Africa codified its attitude towards IIL. The Code has innovative features which reflect the provisions of traditional investment treaties and introduces direct obligations for investors.

The preamble to the Code expresses the noble intentions of Africa in shaping IIL. The objective of the PAIC is to foster sustainable development in Africa. ${ }^{9}$ It transforms traditional investment treaty language by

\footnotetext{
${ }^{1}$ Collins D., An Introduction to international investment law, Cambridge: Cambridge University Press, 2017 , pp. 49.

${ }^{2}$ New Yorke Convention, art. 1(1).

${ }^{3}$ See Strub M. H., "Resisting enforcement of foreign arbitral awards under article V(1)(3) and article VI of the New York Convention: a proposal for effective guidelines", Texas law review 68.5, 1990, pp. 1031-1072.

${ }_{4}^{4}$ Lowenfeld A.F., "The ICSID convention: origins and transformation", Georgia Journal of International and Comparative Law, 38.1, 2009, pp. 47-62; Kidane W., "The China-Africa factor in the contemporary ICSID legitimacy", University of Pennsylvania Journal of International Law, 35.3, 2014, pp. 559-674.

${ }^{5}$ Kamau N., "Investment law and treaty reform in Africa: fragments and fragmentation", African Journal of International Economic Law, 1.1, 2020 , pp. 201-231, at 225.

${ }^{6}$ Mbengue M.M., \& Schacherer S., "Africa and the rethinking of international investment law: about the elaboration of the Pan-African Investment Code", in Roberts A. et al *Eds), Comparative international law, Oxford: Oxford University Press, 2018, pp. 547-569, at 550.

${ }^{7}$ Adopted in October 2017 by the Specialised Technical Committee on Finance, Monetary Affairs, Economic Planning and Integration of the African Union. African Union Commission [AUC], Draft Pan-African Investment Code (Dec. 2016), https://au.int/sites/default/files/documents/32844-doc-draft pan-african investment code december 2016 en.pdf (Accessed 27 July 2021). For a discussion on the PAIC see: Kidane W., "Contemporary international investment law trends and Africa's dilemmas in the Draft PanAfrican Investment Code", George Washington International Law Review, 50.3, 2018, pp. 523-580.

${ }^{8}$ Kamau N., "Investment law and treaty reform in Africa: fragments and fragmentation", African Journal of International Economic Law, 1.1, 2020, pp. 201-231, at 216 .

${ }^{9}$ Art 1 of the PAIC
} 
inserting, for instance, exceptions to many of the standards of protection, such as Most Favoured Nations $(\mathrm{MFN})^{1}$ and national treatment. ${ }^{2}$ The PAIC omits FET clauses on the basis of the contradictory nature of their content and their interpretation by courts and tribunals. ${ }^{3}$ It also introduces horizontal obligations for investors in relation to human rights, ${ }^{4}$ corporate social responsibility, the use of natural resources, and land-grabbing. In its current shape, the Code will promote, facilitate and protect investments that foster the sustainable development of a host African state. ${ }^{5}$

The Code largely presents an opportunity for host states to have the right to regulate. It does not affect the rights and obligations of Member States deriving from any existing investment agreement. ${ }^{6}$ Investors are obliged to adhere to the social-political obligations, ${ }^{7}$ not to engage in bribery, ${ }^{8}$ to fulfil the corporate social responsibility, ${ }^{9}$ as well as to make diligent use of the host state's natural resources. ${ }^{10}$ More intriguing, the Code recognises the importance of enforcing intellectual property rights in relation to investment. ${ }^{11}$ Being mindful of the traditional and genetic values possessed in Africa, the Code reiterates the importance of its preserving African IP rights. It states that:

Member States and investors shall, in accordance with generally accepted international legal standards and best practices, protect traditional knowledge systems and expressions of culture as well as genetic resources that are sought, used or exploited by investors, or are otherwise relevant to their contracts, practices and other operations in such Member States. ${ }^{12}$

The Africanacity of IIL has gone so far as to shape dispute resolution mechanisms provided for in regional investment agreements. ${ }^{13}$ The PAIC gives countries the discretion to implement ISDS. ${ }^{14}$ The ISDS mechanism under PAIC is discussed in detail in the sections of this article below.

PAIC is simply an investment treaty model reflecting the Continent's investment policy. It focuses on the sustainable development goals, which makes it a unique instrument today. It intends its investment policies to be adopted by RECs. What is expected is coherence among the RECs and domestic law. nevertheless, as indicated below, these RECs have adopted distinct approaches in their respective investment model treaties.

The lack of binding force of the PAIC makes it unlikely that African states will adopt a common agenda in the transformation of IIL. It is understandable that the Continent should be divided to some degree in its economic strategies, which might be one of the reasons for having a Continental investment treaty model that lacks legal force. So far, the RECs have not been coherent their treaty models, most of them opting for a model rather than a binding treaty. It might also be due to the previous IIAs that most African countries are reluctant to renegotiate in terms of the new IIL spirit.

\section{IIL in African RECs}

RECs are media to deepening regional integration. They promote socio-economic advancement, political stability, support for human rights and the rule of law, the protection of the sovereignty of national wealth, and sustainable developments. Most RECs have adopted instruments to regulate foreign investment. For investment purposes RECS have embraced a number of significant regional agreements called intra-African Regional Investment Agreements (RIAs). ${ }^{15}$ There are also some RECs whose constituency includes states beyond the African Continent that have adopted a broad and "and less systematic compilation of substantive and procedural provisions on investment." 16

\footnotetext{
${ }^{1}$ Art 8 of the PAIC.

${ }^{2}$ Art 10 of the PAIC

${ }^{3}$ Mbengue M.M., Africa's voice in the formation, shaping and redesign of international investment law, ICSID Rev, 34.1, 2019, pp. 455-481, at 472 .

${ }^{4}$ Art 24 of the PAIC.

${ }^{5}$ Art 1 PAIC.

${ }^{6}$ Art 3 of the PAIC.

${ }^{7}$ Art 20 of the PAIC.

${ }^{8}$ Art 21 of the PAIC.

${ }^{9}$ Art 22 of the PAIC.

${ }^{10}$ Art 23 of the PAIC.

${ }^{11}$ Art 25 of the PAIC

${ }^{12}$ Art 25(3) of the PAIC.

${ }^{13}$ Qumba M.F., "Assessing African regional investment instruments and investor-state dispute settlement", International and Comparative Law Quarterly, 70.1, 2021, pp. 197-232, at 200.

${ }^{14}$ Art 42 of the PAIC.

${ }^{15}$ Chidede T., "The right to regulate in Africa's international investment law regime", Oregon Review of International Law, 20.2, 2019, pp. 437-468, at 449 .

${ }^{16}$ Denters E. \& Gazzini T., "The Role of African regional organizations in the promotion and protection of foreign investment.", Journal of World Investment \& Trade, 18.3, 2017, pp. 449-492, at 451. For further assessment, see: the Community Investment Code of the ECGLC, Jan. 31, 1982, (available at https://investmentpolicyhub.unctad.org/Download/Treaty File/2400) and entered into force on Oct. 4, 1987; the Arab Maghreb Union Investment Agreement, Jul. 23, 1990, and is not yet in force (available at https://investmentpolicyhub.unctad.org/Download/TreatyFile/2405); the Common Convention in Investments in the States of the Customs and Economic Union of Central Africa, Dec. 14, 1965, and entered into force Apr. 1, 1966 (available at
} 
African countries have been negotiating with the European Union on the Economic Partnership Agreements (EPAs) as part of the RECs' arrangements. ${ }^{1}$ Basically, these EPAs concern trade and development commitments. They also contain clauses on the promotion and protection of foreign investment as well as clauses for future negotiations in areas of investment, trade in services, public procurement, and competition. ${ }^{2}$ The United States, on the other hand, has also entered trade and investment agreements with some RECs in the Continent. ${ }^{3}$ Of late, African RECs are IIL rule-makers, after the adoption of a number of investment agreements and treaty models applicable in their respective regions. However, the multiplicity of these instruments suggests that there is a risk of overlapping commitments and uncertainty about the particular investment rules applicable to a particular case. ${ }^{4}$

RECs being the building blocs for the Africanacity of IIL, the transformation has not been particularly coherent. Common feature of the RECs' investment treaty models are the inclusion of new generation investment norms such as sustainable development and investors' obligations. There are discrepancies in approaching ISDS mechanisms. With the existing variables one would even propose the development of a single Continental investment treaty that caters for all AU countries rather than leaving the RECs to develop their own models.

This monograph reveals the Africanacity of IIL in three RECs. These are the Common Market for Eastern and Southern Africa (COMESA), the East African Community (EAC), and the Economic Community of West African States (ECOWAS).

\subsection{Common Market for Eastern and Southern Africa}

In 2007 COMESA adopted the COMESA Common Investment Agreement (CCIA). ${ }^{5}$ The Agreement was revised in order to align it with the PAIC. In an indication of how disjointed efforts to shape IIL in the Continent are, the CCIA is yet to be ratified after its adoption in 2007. Nevertheless, it is the first instrument to set African states on the path of IIL reform.

The CCIA is aligned with the PAIC with some instances. One of the clear distinctions between the two is that the CCIA seems to confine itself to a promotional role. ${ }^{6}$ It reiterates the importance of sustainable development to the member states through joint efforts in liberalising and "promoting" intra-COMESA trade and investment flows. ${ }^{7}$ Contrary to the spirit of "Africanacity", the CCIA encourages its member states to accede to IIAs designed to promote, facilitate and protect investment, such as the New York Convention, the ICSID Convention, the MIGA Convention, the African Trade Insurance Agency, and any other multilateral agreement designed to promote or protect investment. ${ }^{8}$ FET is equated to customary international law and includes a prohibition on the denial of justice. ${ }^{9}$

The agreement deals with foreign investors with substantial business in the COMESA home state, in a way discriminating against African investment. ${ }^{10}$ Further, the CCIA intends to balance rights and obligations between states ${ }^{11}$ and outlines the obligations of investors in accordance with domestic laws. ${ }^{12}$ The agreement also includes provisions providing national treatment and MFN treatment. ${ }^{13}$

\subsection{East African Community}

The legal framework for enhancing investment in the EAC is quite sufficient. The framework at large aims at

https://investmentpolicyhub.unctad.org/Download/TreatyFile/ 2 388); the Agreement on Promotion, Protection and Guarantee of Investments Among Member States of the Organization of the Islamic Conference, June 5, 1981, entered into force on Sept. 23, 1986 (available at https://investmentpolicyhub.unctad.org/Download/TreatyFile/2399); the Agreement on Investment and Free Movement of Arab Capital Among Arab Countries, signed and entered into force on Aug. 29, 1970 (available at https://investmentpolicyhub.unctad.org/Download/TreatyFile/2390).

${ }^{1}$ These EPAs are available at the European Commission website: http://trade.ec.europa.eu/tradchelp/economic-partnership-agreements-cpas (accessed on 25 July 2021).

${ }^{2}$ See, e.g., Art 53 of the EPA between the European Union and the Eastern and Southern Africa States, 2007; Chapter IX of the EPA between the European Union and SADC EPA States, 2016; Art 3 of the EPA between the European Union and EAC, 2014 ; Art 106 of the EPA between the European Union and the West African states, 2014; and Title V of the EPA between the European Union and Central Africa, 2009.

${ }^{3}$ For e.g. see Trade and Investment Framework Agreement between the United States and EAC, signed on Jul. 16, 2008, and entered into force on Jul. 16, 2008.

${ }^{4}$ Mbengue M.M., \& Schacherer S., 2018, at 568.

5 Investment Agreement for the COMESA Common Investment Area, UNCTAD (May 23, 2007),https://investmentpolicy.unctad.org/intemationalinvestmentagreement/treatyfiles/3092/download.

${ }^{6}$ See art 2 of the CCIA

${ }^{7}$ See the Preamble to the CCIA.

${ }^{8}$ Art 6 of the CCIA.

${ }^{9}$ Art 14 of the CCIA.

${ }^{10}$ The criteria for determining substantial business are set out in art 1(4) iii of the CCIA.

${ }^{11}$ Art 11 of the CCIA.

${ }^{12}$ Art 13 of the CCIA.

${ }^{13}$ Art $17-19$ of the CCIA. 
harmonising and nationalising investment incentives with a view to promoting the EAC as a single investment area. The EAC Treaty links industrialisation with investment. ${ }^{1}$ In 2016 the Community adopted the Model Investment Code (EAC Investment Code) ${ }^{2}$ The Code is not binding. Instead, it contains features that member states may domesticate. ${ }^{3}$ It is also a guiding tool for negotiations between EAC Member States and the third states on investment. ${ }^{4}$

Like the PAIC, the EAC Investment Code reiterates the relevance of investment in sustainable development. ${ }^{5}$ The Code affirms the state's right to regulate and rebalance the rights and obligations between states and investors. It promotes national treatment and the nondiscrimination of foreign investors. ${ }^{6}$ Other notable clauses include the prohibition of expropriation except in public interest in accordance with the due process of the law and on payment of fair and adequate compensation within a reasonable time, ${ }^{7}$ and it allows the free transfer of assets and capital. ${ }^{8}$ The Code does not negate international arbitration. It allows investors to submit investment disputes to international arbitration under ICSID rules. ${ }^{9}$

\subsection{Economic Community of West African States}

The ECOWAS adopted the Supplementary Act incorporating Community Rules on Investment and the Modalities for their Implementation with ECOWAS, ${ }^{10}$ and the ECOWAS Energy Charter. ${ }^{11}$ The ECOWAS Supplementary Act is legally binding on ECOWAS member states, investors, and investments. ${ }^{12}$ The Act is an advanced investment treaty that is conscious of the distinctive "context of African countries and adopts a rightsbased approach to development." ${ }^{13}$ The objective of the Act is to promote investment for sustainable development. ${ }^{14}$

The Supplementary Act accords with minimum regional standards, which are equated to the minimum standards under customary international law. ${ }^{15}$ The concepts of "fair and equitable treatment" and full protection and security are included in the standard. ${ }^{16}$ Investors and Investments are subject to the laws and regulations of the host State, ${ }^{17}$ including those on pre-establishment such as environmental impact assessment ${ }^{18}$ and anticorruption regulations. ${ }^{19}$ There are also post-establishment obligations that include hygiene, security, health and social welfare rules in force in the host country. ${ }^{20}$ More importantly, it requires the recognition of human rights, corporate governance ${ }^{21}$ and corporate social responsibility ${ }^{22}$ during investment. Another important feature of the Act is the "investor liability clause". Investors are "subject to civil actions for liability in the judicial process of their host State for acts or decisions made in relation to the investment where such acts or decisions lead to significant damage, personal injuries or loss of life in the host State." ${ }^{23}$ To that effect, the Act gives natural persons the right to sue for damages when suffered in the course of investment. The Act stipulates:

In accordance with the applicable domestic law, a host State or private person or organization, may initiate actions for damages under the domestic law of the host Member State, or the domestic law of the home Member State where such an action relates to the specific conduct of the investor, for damages arising from an alleged breach of the obligations set out in this Supplementary Act. The proceedings in the domestic law Court shall conform to the procedures applicable in the Community

\footnotetext{
${ }^{1}$ Chapter Twelve of the EAC Treaty.

${ }^{2}$ EAC Model Investment Code, 2006

${ }^{3}$ East African Model Investment Code, arts. 5, 3(1)

${ }^{4}$ The Treaty text draws inspiration from the SADC Model BIT 2012, the COMESA Common Investment Area Agreement and the Indian

Model BIT. The draft also acknowledges input from the International Institute for Sustainable Development (IISD).

${ }^{5}$ Preamble of the EAC Investment Code.

${ }^{6}$ Art 5 of the EAC Investment Code.

${ }^{7}$ Art 14 of the EAC Investment Code.

${ }^{8}$ Art 13 of the EAC Investment Code.

${ }^{9}$ Art $15(3)$ of the EAC Investment Code.

${ }^{10}$ Supplementary Act Adopting Community Rules on Investment and the Modalities for Their Implementation with ECOWAS was adopted and signed in December 2008. Supplementary Act A/SA.3/12/08 Adopting Community Rules on Investment and the Modalities for their Implementation with ECOWAS, ECONOMIC COMMUNITY OF WEST AFR. STATES, Dec. 19, 2008, https://investmentpolicyhub.unctad.org/Download/Treaty File/3266 (ECOWAS Supplementary Act).

${ }^{11}$ ECOWAS Energy Protocol was adopted and signed on Jan. 31, 2003.

${ }^{12}$ See art 4 of the Supplementary Act.

${ }^{13}$ Adeleke F. (2017) 144.

${ }^{14}$ Art 3 of the ECOWAS Supplementary Act.

${ }^{15}$ Art 7 of the ECOWAS Supplementary Act.

${ }^{16}$ Art 792) ECOWAS Supplementary Act.

${ }^{17}$ Art 11(1) of the ECOWAS Supplementary Act.

${ }^{18}$ Art 12 of the ECOWAS Supplementary Act.

${ }^{19}$ Art 13 of the ECOWAS Supplementary Act.

${ }^{20}$ Art 14(1) of the ECOWAS Supplementary Act.

${ }^{21}$ Art 15 of the ECOWAS Supplementary Act.

${ }^{22}$ Art 16 of the ECOWAS Supplementary Act.

${ }^{23}$ Art 17 of the ECOWAS Supplementary Act.
} 
Court of Justice. ${ }^{1}$

On the dispute settlement, the Act provides for arbitration when amicable dispute resolution has failed. The investor may submit the dispute to arbitration, to a national court, any national machinery for the settlement of investment disputes, or the relevant court of the Member States. If there is a disagreement on the method of dispute settlement to be adopted, then the dispute is referred to the ECOWAS Court of Justice. ${ }^{2}$ The Act provides a clearer and more elaborate ISDS clause than those of other RECs. It simply negates the international ISDS mechanism.

\section{Domestic level}

African countries have taken distinct measures to acquire the right to regulate IIL. BITs still exist as the most frequently used legal source aiming at guaranteeing investors, according them some rights, duties and benefits, and establishing investment dispute mechanisms. ${ }^{3}$ BITs between developed and developing countries were traditionally concluded (North-South BITs), but, modern BITs are concluded among developing countries from Africa, Asia, and Latin America (South-South BITs). ${ }^{4}$ The nature of most BITs in Africa is what prompted the "africanacity" of IIL. Most of them were dictated by the Western World, leaving the devastated sub-Saharan nations with only a "take-it-or-leave-it" option during negotiations. ${ }^{5}$

The increase in the number of BITs in involving African countries automated their increase in ICSID membership and reach. ${ }^{6}$ BITs involving African states have developed the habit of ending up in an ISDS. Recently, African states have been strongly opposing the existing ISDS mechanisms available under international arbitration. Most concerns have to do with the bias of the arbitrators, the lack of transparency, the lack of independence, the lack of impartiality, and the inconsistent application and interpretation of investment treaties. ${ }^{7}$ Cases such as Al-Kharafi Sons Co v. Libya ${ }^{8}$ motivate African states to dispute the existing ISDS. In that case, the respondent, after terminating the investment agreement, was ordered to pay $\$ 900$ million U.S. Dollars, while the investor had spent only $\$ 130,000$ U.S. Dollars as service compliance fees. Apart from granting what seem to be controversial awards in favour of foreign investors, international arbitral tribunals have a record of discouraging policies protecting national interest.

Over the last decade a number of African states have amended their domestic laws in order to have the right to regulate FDI. ${ }^{9}$ Foresti v. South Africa ${ }^{10}$ is cited as the case that prompted the government of South Africa to take steps to review its investment laws. In that case, foreign investors filed an expropriation claim against South Africa for their mineral rights. The matter was settled on merit. The case faulted South Africa on its expropriation policies. Consequently, the SA government retaliated by beginning to terminate the bulk of its BITs. The review process also recommended an overhaul of its legislative framework. It recommended new pieces of legislation which led to the enactment of several laws concerning investment protection (Protection of Investment Act 22 of 2015), expropriation (Expropriation Act of 2015 and the Property Valuation Act), and arbitration (International Arbitration Act of 2015).

Tanzania has neither enacted nor amended its investment Act. Rather, it recently enacted a number of

\footnotetext{
${ }^{1}$ Art 18(6) of the ECOWAS Supplementary Act.

${ }^{2}$ Art 33 of the ECOWAS Supplementary Act.

${ }^{3}$ To date, there are 2488 BITs involving. all the WTO members. See International Investment Agreements Navigator, UNCTAD, https://investmentpolicy.unctad.org/international-investment-agreements (accessed on 30 September 2021). Also see Sauvant K.P., \& Sachs L.E., The Effect of Treaties on Foreign Direct Investment Bilateral Investment Treaties, Double Taxation Treaties and Investment Flows, Oxford: Oxford University Press, 2009; Investment Policies and Bilateral Investment Treaties in Africa: Implications for Regional Integration. Addis Ababa, Ethiopia: Economic Commission for Africa, 2016; Gazzini T., \& de Brabandere E., international investment law the sources of rights and obligations, Leiden: M. Nijhoff Publishers, 2012

${ }^{4}$ Poulsen L.S., "The politics of south-south bilateral investment treaties", in Broude T., Busch M.L, \& Porges A., The politics of international economic law, Cambridge: Cambridge University Press, 2011, pp. 186-208; Vargiu P. \& Seatzu F., "Africanizing bilateral investment treaties ('BITs'): some case studies and future prospects of a pro-active African approach to international investment", Connecticut Journal of International Law, 30.2, 2015, pp. 143-168.

${ }^{5}$ Van Harten G., "A critique of investment treaties" in Singh K., \& Ilge B., (Eds), Rethinking bilateral investment treaties: critical issues and policy choices", Amsterdam: BOTH ENDS, 2016, pp. 41-50; Johnson A.R., "Rethinking bilateral investment treaties in Sub-Saharan Africa." Emory law journal, 59.4, 2010, pp. 919-967.

${ }^{6}$ Schlemmer E.C., "An Overview of South Africa's Bilateral Investment Treaties and Investment Policy", ICSID Review - Foreign Investment Law Journal, 31.1, 2016, pp. 167-193, at 192.

${ }^{7}$ Billiet J., International investment arbitration: a practical handbook, Maklu: Maklu Publishers, 2016, pp. 84-85.

8 Mohamed Abdulmohsen Al-Kharafi \& Sons Co. v. Libya, Arbitration Award 386, 181 (2013), available at https://www.italaw.com/cases/2185 (accessed on 31 July 2021).

${ }^{9}$ See for example, Algeria Promotion de l'investissement, Loi no 2016-09 (Aug. 3, 2016) (Algeria); Angola (Private Investment Law, Law No. 10/18 (June 26, 2018); Burkina Faso (Loi No 038 2018/AN Portant Codes des Investissements au Burkina Faso (Oct. 30, 2018); Côte d'Ivoire (Ordonnance No 2018-646 du 1er août 2018 Portant Code des Investissements (Aug. 1, 2018); Egypt ( Investment Law No. 27 of 2017 (May 31, 2017); Namibia (Investment Promotion Act, Law No. 199 of 2016, Official Gazette No. 6110 (Aug. 31, 2016); South Africa (Protection of Investment Act 22 of 2015, GN 39514 of GG 606 (15 Dec. 2015); Tunisia (Loi de l'investissement 2016, Loi no 2016-71 (Sept. 30, 2016).

${ }^{10}$ Piero Foresti, Laura de Carli \& Others v. South Africa (ICSID Case No. ARB(AF)/07/1)
} 
"revolutionary" laws to proclaim its permanent sovereignty over its natural resources. ${ }^{1}$ The first legislation is the Natural Wealth and Resources (Permanent Sovereignty) Act, which sets the tone by asserting the Country's sovereignty over its natural resources and emphasising that the resources are for the benefit of the Tanzanian people. The tone is legitimised by referring to international law, the country's Constitution as well as the UN General Assembly Resolution on Permanent Sovereignty over Natural Resources as its First Schedule, and the Charter of the Economic Rights and Duties of States as its Second Schedule. The Act importantly states that: "permanent sovereignty over natural resources shall not be the subject of proceedings in any foreign court or tribunal." Cases of a dispute involving natural wealth and resources "shall be adjudicated by judicial bodies or other organs established in the United Republic and in accordance with the laws of Tanzania." 3 The Act further empowers the National Assembly to review agreements or arrangements related to natural wealth and resources. ${ }^{4}$

The second legislation worth discussing is the Natural Wealth and Resources Contracts (Review and ReNegotiation of Unconscionable Terms) Act. ${ }^{5}$ The legislation mainly empowers the National Assembly to scrutinise natural wealth and resources contracts entered into by the country in order to ensure that they are "concluded in good faith and fairly and, at all times, observe the interests of the People and the United Republic." In doing so, the National Assembly will ascertain whether the agreements or arrangements on natural wealth and resources are unconscionable. if so, it may advise the government to re-negotiate the agreements or arrangements. A term is deemed unconscionable when it deprives the country of the opportunity to exercise permanent sovereignty over its wealth, natural resources and economic activity, ${ }^{7}$ or exposes the country to foreign law and fora. ${ }^{8}$ When the investor state does not come to terms after the re-negotiation, the agreement or arrangement ceases and is treated as having no binding effect, as if it had been expunged. ${ }^{9}$

Further, the Written Laws (Miscellaneous Amendments) Act ${ }^{10}$ gives more authority to the Tanzanian government over its natural resources, after amending the Mining and Petroleum legislation. The amendments are in accordance with contemporary principles such as national interest, sustainability and environmental protection. ${ }^{11}$ With the Public Private Partnership Amendment Act, ${ }^{12}$ it negates international arbitration. Instead, the Act encourages disputes arising from the agreements to be settled by negotiations or "in the case of mediation or arbitration, [to] be adjudicated by judicial bodes or other organs established in the United Republic and in accordance with the laws of Tanzania."13

These laws intend to give Tanzania the upper hand in regulating foreign investment relationships. Significantly, the laws exclusively recognise domestic law and fora in ISDS mechanisms in all matters involving the Country's natural resources.

\section{Investor-state dispute system}

The most important feature of any IIA is the investor-state dispute clause. ${ }^{14}$ The clause guarantees the parties a natural forum in case of a future dispute. These clauses are mostly seen to be for the protection of investors' rights. ${ }^{15}$ In the midst of African protest against the "biased-imperialist" ISDS system, African regional trade agreements have resorted to establishing regional and national mechanisms for adjudicating investment disputes. ${ }^{16}$ ISDS mechanisms shield investors from any political pressure that might appear in the domestic forums of a host-state. ${ }^{17}$ Debates over the relevance and legitimacy of the ISDS mechanism will never cease, even in the imagination of the author of this article. ${ }^{18}$

The resurgence in the development of home-made ISDS mechanisms in Africa is indicative of

\footnotetext{
${ }^{1}$ The Natural Wealth and Resources (Permanent Sovereignty) Act No 5 of 2017; The Natural Wealth and Resources Contracts (Review and Re-Negotiation of Unconscionable Terms) Act, No. 6 of 2017; The Public Private Partnership (Amendment) Act, No. 9 of 2018 (Sept. 25 , 2018)

${ }^{2}$ Sec 11(1) of Act No. 5 of 2017.

${ }^{3}$ Sec 11(2) of Act No. 5 of 2017.

${ }^{4}$ Sec 12 of Act No. 5 of 2017.

${ }^{5}$ The Natural Wealth and Resources Contracts (Review and Re-Negotiation of Unconscionable Terms) Act, No. 6 of 2017.

${ }^{6} \mathrm{Sec} 4(2)$ of Act No. 6 of 2017.

${ }^{7} \mathrm{Sec} 6(2)(\mathrm{a})$ of Act No. 6 of 2017.

${ }^{8} \mathrm{Sec} 6$ (2)(i) of Act No. 6 of 2017.

${ }^{9}$ Sec 7 of Act No 6 of 2017.

${ }^{10}$ The Written Laws (Miscellaneous Amendments) Act No. 2 of 2017.

${ }^{11}$ Sec 30 of Act No. 2 of 2017.

${ }^{12}$ The Public Private Partnership (Amendment) Act No. 9 of 2018.

${ }^{13}$ Sec 14 of Act No. 9 of 2017.

${ }^{14}$ Sornarajah M, The international law and foreign investment, Cambridge: Cambridge University Press, 2004 , at pp. 216.

${ }^{15}$ As above, at 217.

${ }^{16}$ See Qumba M.F., 2021, pp. 197-232

${ }^{17}$ Gas Natural SDG S.A v The Argentine Republic, ICSID Case No ARB/03/10, Award (17 June 2005).

${ }^{18}$ See Brower C. N., \& Schill S.W., "Is arbitration a threat or a boon to the legitimacy of international investment law?," Chicago Journal of International Law, 9.2, 471-498; Trakman L.E., "The ICSID Under Siege”, Cornell International Law Journal, 45.3, 2012, pp. 602-665
} 
dissatisfaction of African states with the traditional ISDS. ${ }^{1}$ Looking at the PAIC, it affords African states a middle-ground solution with the option of accepting or rejecting ISDS mechanism. The PAIC requires member states to recognise ISDS "in line with their domestic policies". ${ }^{2}$ Under article 42(1)(b) the Code urges the resolution of disputes through consultation and negotiation. If the consultation fails, the Code allows for arbitration but subject to the host-state's law and policy. ${ }^{3}$ Article $42(1)$ (c) further introduces the use of local remedy requirement before going to arbitration. In terms of national laws such as those of Tanzania, which negate the ISDS mechanism, foreign firms are barred from referring disputes for arbitration to the ICSID or any other international body. ${ }^{4}$

The ECOWAS Supplementary Act clearly protects the citizens of host-states by providing a clause on investors' liability. ${ }^{5}$ Investors can be liable for damage caused due to their actions and decisions. The Act enshrines a more restrictive ISDS mechanism clause. It allows ISDS on the premises through arbitration at national courts or national investment arbitration centres. ${ }^{6}$ Simply put, the ECOWAS Supplementary Act completely negates international ISDS mechanisms.

The CCIA does not negate ISDS. The investor can opt between domestic courts, the COMESA Court of Justice or international arbitration under ICSID Rules, the ICSID Additional Facility Rules, the UNCITRAL Rules, or the rules of any other arbitral institution agreed to by the parties. ${ }^{7}$

There is an increased desire among African nations to avoid arbitration in disputes involving natural resources. It is at this juncture that the spirit of Africanacity finds itself between a rock and a hard place, that is, in trying to attract investors on the one hand and in protecting national interests and natural wealth on the other hand. It is clear that there is a feeling that the existing ISDS mechanisms are biased. While such assertions might be hard to prove, they need to be addressed in order to protect the legitimacy of IIL. Yet Africa cannot design an IIL system of its own. It must be legitimate and credible to all, globally. Foreign investors may feel that the proposed local ISDS is likely to be equally biased. It is unlikely that a foreign investor will risk investing in a country where there is no guarantee of challenging malpractice before an independent judicial body.

In an arbitration, for example, parties are allowed to use an arbitrator of their own choice. In such a situation one may even ponder the issue of the bias of ISDS mechanisms. It is also undeniable that many investments in Africa are frustrated by African governments themselves through acts such as corruption, expropriation without fair and adequate compensation, and a lack of or untimely investment in the particular project. It is often such malpractices by African states that are faulted before international arbitral bodies.

\section{Conclusion}

For many years, African states have positioned themselves as investment rule-takers. This is partly due to the asymmetry in economic balance between the host African countries and the investing nations. Consequently, the imbalance has led to the contemporary transformation of the traditional IIL regime. In return, African states are being caught between the need to attract foreign investors, on the one hand, and the desire to preserve investorstate rights and obligations, on the other hand. ${ }^{8}$ Nevertheless, the reforms, which intend to reshape the IIL

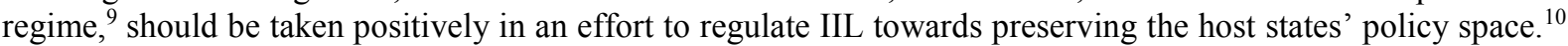
With the establishment of regional and domestic arbitration institutions in Africa, this might be a gesture that the Continent is somehow attempting to snub ICSID. ${ }^{11}$ In that regard, I am posing a challenge that local institutions vested in settling international investment disputes must be credible and staffed with acclaimed experts. They must demonstrate their independence and impartiality, and not be purposed to protect the interests of the hoststate per se. Otherwise, just as Africa is opposing the traditional "imperialist" IIL regime that include the current ISDS mechanisms, the new "African" regime will certainly be similarly affronted by foreign investors.

\section{INTERNATIONAL INSTRUMENTS}

Agreement on Investment and Free Movement of Arab Capital Among Arab Countries, 1970

Agreement on Promotion, Protection and Guarantee of Investments Among Member States of the Organization

\footnotetext{
${ }^{1}$ Qumba M.F., 2021, at 202

${ }^{2}$ Art $42(1)$ of the PAIC.

${ }^{3}$ Art $41(2)$ of the PAIC.

${ }^{4}$ See also the Protection of Investment Act 22 of 2015, sec 13.

${ }^{5}$ Art 17 of the ECOWAS Supplementary Act.

${ }^{6}$ Art 33(6) of the ECOWAS Supplementary Act.

${ }^{7}$ Art 28 of the CCIA

${ }^{8}$ See Stern B., "The future of international investment law: a balance between the protection of investors and the states' capacity to regulate", in Alvarez J.E., \& Sauvant K.P., (Eds) The evolving international investment regime: expectations, realities, options, Oxford: Oxford University Press, 2011, pp 174-189.

${ }^{9}$ See Akinkugbe O.D., 2019, pp. 434-454.

${ }^{10}$ Denters E. \& Gazzini T., 2017, pp. 449-492, at 492.

${ }^{11}$ Also see Agyemang A.A., "African states and ICSID arbitration", Comparative and International Law Journal of Southern Africa, 21.2, 1988 , pp. $177-189$, at 178 .
} 
of the Islamic Conference, 1981

Agreement on Trade-Related Investment Measures, Annex IA, Apr. 15, 1994, 1868 U.N.T.S. 186.

General Agreement on Trade in Services, Annex IB, Apr. 15, 1994, 1869 U.N.T.S. 183, 33 I.L.M. 1167

Arab Maghreb Union Investment Agreement, 1990

Common Market for Eastern and Southern Africa, Investment Agreement for the COMESA Common Investment Area, 2007

Community Investment Code of the ECGLC, 1982

Common Convention in Investments in the States of the Customs and Economic Union of Central Africa, 1965

Convention on the Settlement of Investment Disputes Between States and Nationals of Other States, Oct. 14, 1966, 575 U.N.T.S. 159

Convention Establishing the Multilateral Investment Guarantee Agency, Oct. 11, 1985, 1508 U.N.T.S. 99. The MIGA Convention was signed in 1985 and came into operation in 1988

Convention on the Recognition and Enforcement of Foreign Arbitral Awards, May 20, 1958, 330 U.N.T.S. 38

Pan-African Investment Code, 2016

ECOWAS Supplementary Act, 2008

ECOWAS Energy Protocol, 2003

EPA Agreement, European Union and the Eastern and Southern Africa States, 2007

EPA Agreement, European Union and EAC, 2014

EPA Agreement, European Union and SADC EPA States, 2016

EPA Agreement, European Union and the West African states, 2014

EPA Agreement, European Union and Central Africa, 2009

Southern African Development Community has (SADC) adopted the Finance and Investment Protocol, 2006

SADC Model Bilateral Investment Treaty Template, SADC (Jul. 2012), https://www.iisd.org/itn/wpcontent/uploads/2012/1 0/sadc-model-bit-template-final.pdf.

Trade and Investment Framework Agreement between the United States and EAC, 2008,

\section{DOMESTIC LAW}

Algeria

Promotion de l'investissement, Loi no 2016-09 (Aug. 3, 2016)

Angola

Private Investment Law, Law No. 10/18 (June 26, 2018)

Burkina Faso

Loi No 038 2018/AN Portant Codes des Investissements au Burkina Faso (Oct. 30, 2018)

Côte d'Ivoire

Ordonnance $N^{\circ}$ 2018-646 du 1er août 2018 Portant Code des Investissements (Aug. 1, 2018)

Egypt

Investment Law No. 27 of 2017 (May 31, 2017);

Namibia

Investment Promotion Act, Law No. 199 of 2016, Official Gazette No. 6110 (Aug. 31, 2016)

South Africa

(Protection of Investment Act 22 of 2015, GN 39514 of GG 606 (15 Dec. 2015)

Tunisia

(Loi de l'investissement 2016, Loi no 2016-71 (Sept. 30, 2016)

Tanzania

Arbitration Act No. 2 of 2020

Natural Wealth and Resources (Permanent Sovereignty) Act No 5 of 2017

Natural Wealth and Resources Contracts (Review and Re-Negotiation of Unconscionable Terms) Act, No. 6 of 2017

The Written Laws (Miscellaneous Amendments) Act, No. 2 of 2017

The Public Private Partnership (Amendment) Act, No. 9 of 2018

\section{CASE LAW}

Gas Natural SDG S.Av The Argentine Republic, ICSID Case No ARB/03/10, Award (17 June 2005).

Piero Foresti, Laura de Carli \& Others v. South Africa (ICSID Case No. ARB(AF)/07/1)

Mohamed Abdulmohsen Al-Kharafi \& Sons Co. v. Libya, Arbitrarion Award 386, 181 (2013)

\section{BOOKS}

Adeleke F., international investment law and policy in Africa: exploring a human rights based approach to investment regulation and dispute settlement, Oxon: Routledge, 2017 
Billiet J., International investment arbitration: a practical handbook, Maklu: Maklu Publishers, 2016 Collins D., An Introduction to international investment law, Cambridge: Cambridge University Press, 2017

Gazzini T. \& de. Brabandere E., international investment law the sources of rights and obligations, Leiden : M. Nijhoff Publishers, 2012

Indira C., Hossain J.B., \& Alam S., International Trade Law and the WTO, Annandale, N.S.W: Federation Press, 2013

Keet D., The World Trade Organisation: General Agreement on Trade in Services: from forcing "liberalisation" to reinforcing privatisation!: from the further "opening up" of all economies to the furthering re-colonisation, Cape Town: Alternative Information and Development Centre, 2003.

Kimbugwe K., Economic development through regional trade : a role for the new East African Community?, Houndmills, Hampshire :, Palgrave Macmillan, 2012

Nagar D. \& Mutasa C. (eds), Africa and the world: bilateral and multilateral international diplomacy, Cham: Springer International Publishing AG, 2018.

Odularu G., \& Bamidele A., Negotiating south-south regional trade agreements : economic opportunities and policy directions for Africa, Cham, Springer Nature, 2017.

Mbengue, M.M, \& Ngangjoh-Hodu Y. (eds), African Perspectives in International Investment Law . Manchester, England: Manchester University Press, 2020

Sauvant K. P., \& Lisa E. S., The effect of treaties on foreign direct investment: bilateral investment treaties, double taxation treaties, and investment flows, New York: Oxford University Press, 2009

Sornarajah M., The International Law on Foreign Investment, Cambridge: Cambridge University Press, 2010

Van Harten G., Investment treaty arbitration and public law, Oxford: Oxford University Press, 2009

\section{CHAPTERS IN A BOOK}

Bezuidenhout H., "Foreign direct investment and trade in the Southern African Development Community", in Santos-Paulino A.U. \& Wan G., Southern engines of global growth, Oxford: Oxford University Press, 2010, pp. $1-25$

Laryea E.T., \& Sucker F., "The importance of an African voice in, and understanding and use of, international economic law" in Ezeani, E.C., Laryea E.T., Madolo N., \& Sucker F., (eds), International Economic Law: Voices of Africa, Cape Town: Siber Ink, 2012, pp. 1-13.

Mbengue M.M. \& Schacherer S., "Africa and the rethinking of international investment law: about the elaboration of the Pan-African Investment Code", in Roberts A. et al, Comparative international law, Oxford: Oxford University Press, 2018, pp. 547-569

Poulsen L.S., "The politics of south-south bilateral investment treaties", in Broude T., Busch M.L, \& Porges A., The politics of international economic law, Cambridge: Cambridge University Press, 2011, pp. 186-208

Stern B., "The future of international investment law: a balance between the protection of investors and the states' capacity to regulate", in Alvarez J.E., \& Sauvant K.P., (Eds) The evolving international investment regime: expectations, realities, options, Oxford: Oxford University Press, 2011, pp 174-189

Van Harten G., "A critique of investment treaties" in Singh K., \& Ilge B., (Eds), Rethinking bilateral investment treaties: critical issues and policy choices”, Amsterdam: BOTH ENDS, 2016, pp. 41-50

\section{JOURNAL ARTICLES}

Adams K., Debrah Y.A., Williams K., Mmieh F., "Causes of Financial FDI Inflows into Sub-Saharan Africa evidence from Ghana”, Thunderbird International Business Review, 56.5, 2014, pp. 439-459

Akinkugbe O.D., "Theorizing developmental regionalism in narratives of African regional trade agreements", African Journal of International Economic Law, 1.1, 2020, pp. 291-320.

Akinkugbe, O.D., "Africanization and the reform of international investment law", Case Western Reserve Journal of International Law, 53.1, 2021, pp. 7-32

Brower C. N., \& Schill S.W., "Is arbitration a threat or a boon to the legitimacy of international investment law?," Chicago Journal of International Law, 9.2, 471-498

Asante S.K.B., "international law and foreign investment: a reappraisal", The International and Comparative Law Quarterly, 37.3, 1988, pp. 588-628

Chidede T., "The right to regulate in Africa's international investment law regime", Oregon Review of International Law, 20.2, 2019, p. 437-468

Cleeve E.A, Debrah Y., \& Yiheyis Z., "Human capital and FDI inflow: an Assessment of the African case", World Development, 74.c, 2015, pp. 1-14

Dagbanja D., "Can African countries attract investments without bilateral investment treaties? example from Ghana, The Australasian Review of African Studies, 40.2., 2019, pp. 71-89.

Denters E. \& Gazzini T., "The Role of African regional organizations in the promotion and protection of foreign investment.", Journal of World Investment \& Trade, 18.3, 2017, pp. 449-492 
Fox G., "A Future for International Investment: modifying Bits to Drive Economic Development," Georgetown Journal of International Law, 46.1, 2014, pp. 229-260

Gathii J.T., "Agreement Establishing the African Continental Free Trade Area", International legal materials, $58.5,2019$, p. $1028-1083$

Gathii J.T., "African regional trade agreements as flexible legal regimes" North Carolina Journal of International Law \& Commercial Regulation, 35. 3, 2010, pp. 571-668

Ho J. "The creation of elusive investor responsibility," American Journal of International Law, 113, 2019, pp. $10-15$.

Johnson A.R., "Rethinking bilateral investment treaties in Sub-Saharan Africa." Emory law journal, 59.4, 2010, pp. 919-967

Kamau N., "Investment law and treaty reform in Africa: fragments and fragmentation", African Journal of International Economic Law, 1.1, 2020, pp. 201-231

Kidane W., "The China-Africa factor in the contemporary ICSID legitimacy", University of Pennsylvania Journal of International Law, 35.3, 2014, pp. 559-674

Kidane W., "Contemporary international investment law trends and Africa's dilemmas in the Draft Pan-African Investment Code", George Washington International Law Review, 50.3, 2018, pp. 523-580

Lowenfeld A.F., "The ICSID convention: origins and transformation", Georgia Journal of International and Comparative Law, 38.1, 2009, pp. 47-62

Mbengue M.M. \& Schacherer S., “The 'Africanization' of international investment law: the pan-African investment code and the reform of the international investment regime", Journal of World Investment \& Trade, 18.3 , p. $437-448$

Odumosu I.T., "The antinomies of the (continued) relevance of icsid to the third world", San Diego International Law Journal , 8.1, 2007, pp. 345-384.

Nam J., "Model bit: an ideal prototype or a tool for efficient breach?", Georgetown journal of international law, 48.4, 2017, pp. 1275-1308

Rowat M.D., "Multilateral approaches to improving the investment climate of developing countries: the cases of ICSID and MIGA", Harvard International Law Journal, 33., 1992, pp. 103-144

Nwankwo C.M., "Balancing international investment law and climate change in Africa: assessing vertical and horizontal norms", Manchester Journal of International Economic Law, 17.1, 2020, pp. 48-63

Osmanski E., "Investor-state dispute settlement: is there a better alternative", Brooklyn Journal of International Law, 43.2, 2018, pp. 639-664.

Peter C.M., "MIGA and GRIP: two international investment insurance programmes", World Competition, 12.3, 1989, pp. 95-104

Qumba M.F., “Assessing African regional investment instruments and investor-state dispute settlement”, International and Comparative Law Quarterly, 70.1, 2021, pp. 197-232

Schultz T., \& Dupont C., "Investment arbitration: promoting the rule of law or over-empowering investors? a quantitative empirical study", European Journal of International Law, 25. 4, 2014, pp. 1147-1168

Schlemmer E.C., "An Overview of South Africa's bilateral investment treaties and investment policy", ICSID Review - Foreign Investment Law Journal, 31.1, 2016, pp. 167-193

Schill S.W., "The new African regionalism in international investment Law", Journal of World Investment \& Trade, 18.3, 2017, pp. 367-369

Sornarajah M, The international law and foreign investment, Cambridge: Cambridge University Press, 2004

Strub, M. H., "Resisting enforcement of foreign arbitral awards under article V(1)(3) and article VI of the New York Convention: a proposal for effective guidelines", Texas law review 68.5, 1990, pp. 1031-1072

Schwartz P., "Capitalism, international investment law and the development conundrum", Law and Development Review, 6.2, pp. 217-254

Trakman L.E., "The ICSID Under Siege", Cornell International Law Journal, 45.3, 2012, pp. 602-665

Vandevelde K.J., "The political economy of a bilateral investment treaty", American Journal of International Law 92. 4, 1998, pp. 621-641

Van Harten G., "Five justifications for investment treaties: a critical discussion", Trade, Law \& Development, 2.1, 2010, pp. 19-58

Vargiu P. \& Seatzu F., "Africanizing bilateral investment treaties ('BITs'): some case studies and future prospects of a pro-active African approach to international investment", Connecticut Journal of International Law, 30.2, 2015, pp. 143-168

\section{Internet sources}

European Commission website: http://trade.ec.europa.eu/tradchelp/economic-partnership-agreements-cpas (accessed 26 July 2021)

International Investment Agreements Navigator, UNCTAD, https://investmentpolicy.unctad.org/international- 
investment-agreements (accessed on 30 July 2021).

Investment policies and bilateral investment treaties in Africa: implications for regional integration, United
Nations
Economic
Commission
For
Africa
(Feb.
2016),

https://www.uneca.org/sites/default/files/PublicationFiles/eng (accessed 24 July 2021).

Cotula L, 'International law and negotiating power in foreign investment projects: comparing property rights protection under human rights and investment law in Africa' (2008) 33 South African Yearbook of International Law 62 